www.jmscr.igmpublication.org

Impact Factor 5.244

Index Copernicus Value: 5.88

ISSN (e)-2347-176x ISSN (p) 2455-0450

crossref DOI: _http://dx.doi.org/10.18535/jmscr/v4i4.45

Journal Of Medical Science And Clinical Research

IGM Publication

An official Publication of IGM Publication

\title{
Neonatal Screening Program, Study of Congenital Hypothyroidism Cases
}

\author{
Authors \\ Dr Basil Metti Hanoudi, Najla I.Ayoub, Rasha S. Abdulraheem \\ Al Mustaansiriya University, College of Medicine \\ Email: basilhanoudi@yahoo.com
}

\begin{abstract}
Introduction: Congenital hypothyroidism is one of the most common preventable causes of mental retardation. The clinical manifestations are so subtle that many newborns are undiagnosed at birth.

Aim of study: Studying neonatal screening in Baghdad city and cases of hypothyroidism in screened infants, regarding; clinical presentation, treatment and follow up of cases.

Patients and methods: A retrospective descriptive study was done in Baghdad city for babies screened over the period $1^{\text {st }}$ of Nov 2015 to $31^{\text {st }}$ of Jan 2016. Data about screening program was collected over the period of $1^{\text {st }}$ April 2013 to $31^{\text {st }}$ October 2015 and $1^{\text {st }}$ May 2013 to $31^{\text {st }}$ October 2015 respectively.

Results: The total number of screened newborns was 441206 (249835 in Al-Rusafa and 191371 newborns in Al-Karkh) with average screening coverage of 59.9\%. The overall proportion of occurrence of congenital hypothyroidism was 1:2141, phenylketonuria 1:6787, and galactosemia 1:21009. The study group included screened newborns patients from Al-Karkh hospitals (24 patients). The female: Male ratio patients in AlKarkh was 1.6:1. There was a significant association of positive linear growth increment in symptomatic group of patients $(P$ 0.044). A positive change in linear growth showed significantly younger aged patients $(P 0.025)$ and higher admission TSH level than no change (P 0.001). There was a significantly higher level of admission TSH in delayed developmental milestone in the study group of patients (P 0.016).
\end{abstract}

Conclusion: *Efforts to bypass the drawbacks of work routines

*Enhance and encourage public education for notification of confirmed cases to attend tertiary centers

Key words: neonatal screening, hypothyroidism, development assessment, thyroxine, clinical features

\section{Introduction}

The newborn screening program in Iraq is a pilot primary health care project. Screening is the first step in a two-step process, the primitive first test indicates a problem, while the second test is confirmative of diagnosis. Program that has been started on April, 2013 to cover newborns in Baghdad and Karbala governorates. Screening is done for congenital hypothyroidism (CHT), phenylketonuria (PKU), and galactosemia (GAL). ${ }^{(1)}$ Congenital hypothyroidism is one of the most common preventable causes of mental retardation and occurs in 1:2,000-1:4,000 newborns. ${ }^{(2)}$ 
Hypothyroidism results from deficient thyroid hormone production, primary hypothyroidism related a defect in the gland itself, or central or hypopituitary hypothyroidism due to reduced thyroid-stimulating hormone (TSH) stimulation. Early life manifestation refers to untreated congenital type, while symptoms appearing after a period of normal thyroid function is related to acquired hypothyroidism. ${ }^{(3)}$

Most cases of congenital hypothyroidism (CHT) are not hereditary and result from dysgenesis of thyroid gland, while some cases are familial and related to inborn errors of thyroid hormone synthesis (dyshormonogenesis) and may be associated with a goiter. ${ }^{(3)}$

\section{Aim of study}

1. Studying neonatal screening in Baghdad city and cases of hypothyroidism in screened infants

2. Study clinical presentation, treatment and follow up of CHT cases

\section{Patients and methods}

A retrospective descriptive study is done in Baghdad city for babies screened over the period $1^{\text {st }}$ of Nov 2015 to $31^{\text {st }}$ of Jan 2016. Screening method and rule were according to the national guideline of newborn screening (U.S. Agency). ${ }^{(1)}$ Screening include babies at optimum age of 72 hours -5 days of life and up to 2 months regardless the gestational age in primary care health centers (PHC). Blood sampling is collected through pricking baby's heel and the sample of blood is dried onto a filter paper and mailed to the Central Public Health Laboratory (CPHL) in Baghdad after filling the general data on data sheet (sex, PHC name, newborn name and mother's name, home address, mobile number, place and date of delivery, date of sampling, name of specimen submitter). Newborns blood samples are first processed in a primitive test, and are followed by a confirmative diagnostic test if the first testing is positive.

Regarding tests implemented were according to the national guideline of newborn screening (U.S. Agency) (1), the primitive tests; in CHT, a DELFIA nTSH (time resolved fluoroimmunoassay) is done, phenylketonuria (PKU) is detected by phenylalanine kit making use of fluorescent ninhydrin method, and neonatal total galactose kit makes use of a fluorescent galactose oxidase method. In case of a positive result in primitive tests, the confirmative diagnostic tests are done by; TSH and free $\mathrm{T}_{4}$ enzyme linked fluorescent assay (ELFA) for CHT, electrospray ionization tandam mass spectrometry for phenylketonuria, and spectrophotometery of galactose 1-p uridyltransferase for galactosemia. In case of positive confirmative test, the newborn is recalled via mobile number and address given to start management in relevant tertiary center.

Data about screening program was collected from Al-Rusafa and Al-Karkh general health directorates/ ministry of health, for the period of $1^{\text {st }}$ April 2013 to $31^{\text {st }}$ October 2015 and $1^{\text {st }}$ May 2013 to $31^{\text {st }}$ October 2015 respectively. Data about and patients confirmed to have CHT was collected from main four centers of referral hospitals in Baghdad (central child teaching hospital, Al-Imamian Al-Jawadian teaching hospital, Al-Elwiya teaching hospital, and Iben Albaladi hospital), after proper consent of Al-Rusafa and Al-Karkh general health directorates was obtained.

Patient's data included; name, gender, age at reception of patient, age of patient at time of research, residence, clinical signs at reception (sluggish, constipation, umbilical hernia, respiratory difficulty, wide fontanel, protruded tongue, coarse features, subnormal temperature, neonatal jaundice), family history of hypothyroidism, consequanity (near or far cousins/none), growth parameters (no change in normal growth centile, positive change in growth centile, or negative change in growth centile) ${ }^{(4)}$, developmental assessment up to date (compatible to age or delayed to age), admission TSH and $\mathrm{T}_{4}$ level, starting dose and 
control dose of levothyroxine and period to reach control dose, and skip cases. Incomplete or deficient files of patient's data were ignored in analysis of data.

Regarding CHT, management is started immediately after diagnosis is confirmed by serum confirmative test, physical examination. Treatment is started by levothyroxine tablet (crashed and dissolved into water of formula) in dose of; $10-15 \mu \mathrm{g} / \mathrm{Kg} /$ day (maximum dose of $50 \mu \mathrm{g} /$ day ) and may be reduced afterwards

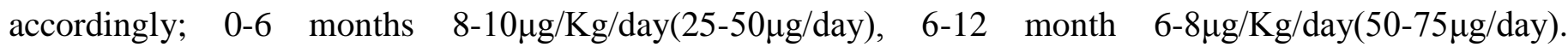
Rechecking $\mathrm{T}_{4}$ and TSH was done; 2-4 weeks after starting treatment, every 1-2 months in $1^{\text {st }} 6$ months, every 3-4 month between 6 months to 3 years of life, every 6-12 month from 3 year and afterwards. Children are monitored and followed up through height, weight, and developmental assessment. ${ }^{(1)}$

The data was managed with computer software SPSS version 21. Chi square test was done to define the association between the categorical variables. $\mathrm{P}$ value equal to or less than 0.05 was considered significant and less than 0.01 was considered highly significant.

\section{Results}

The number of screened newborns over the period of $1^{\text {st }}$ April 2013 to $31^{\text {st }}$ October 2015 were 249835 newborns in Al-Rusafa side of Baghdad city with average screening coverage of $59.4 \%$, and the number of screened newborns over the period of $1^{\text {st }}$ May 2013 to $31^{\text {st }}$ October 2015 (screening started with one month delay) were 191371 newborns in Al-Karkh side of Baghdad city with average screening coverage of 60.7\%. Lack of filter paper, poor communication (in-between CPHL, health directorates, and PHC centers), delay of initial vaccination visit, and lack of awareness of program were encountered during study.

Table 1: The total monthly coverage percentages of live newborns with neonatal screening program in Baghdad

\begin{tabular}{|c|c|c|c|c|c|c|c|c|}
\hline 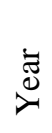 & Period & $\begin{array}{l}\text { Target No. } \\
\text { in Al-Rusafa }\end{array}$ & $\begin{array}{l}\text { screened } \\
\text { newborns in } \\
\text { Al-Rusafa }\end{array}$ & $\begin{array}{l}\text { Coverage \% in } \\
\text { Al-Rusafa }\end{array}$ & Period & $\begin{array}{ll}\text { Target } & \text { No. } \\
\text { in } & \text { Al- } \\
\text { karkh } & \end{array}$ & $\begin{array}{l}\text { screened } \\
\text { newborns in } \\
\text { Al-karkh }\end{array}$ & $\begin{array}{l}\text { Coverage } \\
\% \text { in Al- } \\
\text { Karkh }\end{array}$ \\
\hline$\stackrel{m}{\stackrel{n}{N}}$ & $\begin{array}{l}\text { April- } \\
\text { Dec. }\end{array}$ & 113739 & 52208 & $45.9 \%$ & $\begin{array}{l}\text { May - } \\
\text { Dec. }\end{array}$ & 94928 & 47055 & $49.6 \%$ \\
\hline$\stackrel{+}{\circ}$ & $\begin{array}{l}\text { Jan.- } \\
\text { Dec. }\end{array}$ & 163289 & 114779 & $70.3 \%$ & $\begin{array}{l}\text { Jan.- } \\
\text { Dec. }\end{array}$ & 122009 & 80409 & $65.9 \%$ \\
\hline$\stackrel{n}{\stackrel{n}{c}}$ & $\begin{array}{l}\text { Jan.- } \\
\text { Oct. }\end{array}$ & 143460 & 82848 & $57.7 \%$ & $\begin{array}{l}\text { Jan.- } \\
\text { Oct. }\end{array}$ & 98270 & 63907 & $65.0 \%$ \\
\hline \multicolumn{2}{|c|}{ Total } & 420488 & 249835 & $59.4 \%$ & Total & 315207 & 191371 & $60.7 \%$ \\
\hline
\end{tabular}

Of total 249835 screened newborns in Al-Rusafa over the study period, , there were 154 confirmed positive cases of; CHT (96 case), phenylketonuria (46 case) and galactosemia (12 case). Of total 190749 screened newborns in Al-Karkh over the study period, there were 143 confirmed positive cases; CHT (110 case), phenylketonuria (14 case), and galactosemia (9 case). 
Table 2: The proportion of occurrence of congenital hypothyroidism, phenylketonuria, and galactosemia in Baghdad over the study period (confirmed cases).

\begin{tabular}{|c|c|c|c|c|c|c|c|}
\hline & Period of screening & CHT & Pro & PKU & Pro & GAL & Pro \\
\hline 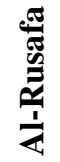 & Of total screened (249835) & 96 & $1: 2602$ & 46 & $1: 5431$ & 12 & 1:20819 \\
\hline $\begin{array}{l}\frac{\pi}{x} \\
\frac{\pi}{\pi} \\
\frac{\pi}{2}\end{array}$ & Of total screened (191371) & 110 & 1:1739 & 19 & 1:10072 & 9 & $1: 21263$ \\
\hline & $\begin{array}{l}\text { Over all total screened } \\
(\mathbf{4 4 1 2 0 6 )}\end{array}$ & 206 & 1:2141 & 65 & 1:6787 & 21 & 1:21009 \\
\hline
\end{tabular}

Pro, proportion of occurrence

The overall proportion of occurrence of CHT during the study period is $1: 2141$, of PKU is 1:6787, and Gal is $1: 21009$

Regarding CHT; Out of 206 patients diagnosed and confirmed in Baghdad over the period of $1^{\text {st }}$ May 2013 to $31^{\text {st }}$ October 2015 , only 90 patients $(43.7 \%)$ were notified, attended and registered in the tertiary hospitals, and three of them had discontinued treatment and follow up. The study group included the confirmed and screened newborn patients from Al-Karkh; Al-Imamian Al-Jawadian Teaching Hospital, and Child Central Teaching Hospital, who had a meticulous recording of data and follow up (24 patients). The female : Male patients in Al-Karkh health directorate were 15:9, with 1.6:1ratio. Seven patients of them were asymptomatic (29.2\%), while 17 patients $(70.8 \%)$ were symptomatic. Constipation, sluggish movement, and neonatal jaundice were the most frequent clinical signs in the symptomatic patients of the study group.

Table 3: Frequency distribution of the different clinical signs within the symptomatic patients (n 17) of the study group in Al-Karkh (n 24)

\begin{tabular}{|l|c|c|}
\hline Clinical sign & Symptomatic patients (n 17) & \% \\
\hline Constipation & 11 & $65 \%$ \\
\hline Sluggish & 9 & $53 \%$ \\
\hline Neonatal jaundice & 8 & $47 \%$ \\
\hline Umbilical hernia & 6 & $35 \%$ \\
\hline Respiratory difficulty & 5 & $29 \%$ \\
\hline Coarse features & 2 & $12 \%$ \\
\hline Feeding difficulty & 2 & $12 \%$ \\
\hline Wide fontanel & 2 & $12 \%$ \\
\hline Protruded tongue & 2 & $12 \%$ \\
\hline Subnormal temperature & 1 & $6 \%$ \\
\hline
\end{tabular}


A descriptive statistics of the continuous variables of the study group is shown in table 4

Table 4. Descriptive statistics of study group patients according to the continuous variables (n 24).

\begin{tabular}{|l|l|l|l|l|}
\hline Variable & Mean & \pm SD & Minimum & Maximum \\
\hline Age at first reception in tertiary center (days) & 53.58 & 25.83 & 7 & 120 \\
\hline Age at time of research $($ months) & 18.35 & 9.41 & 2 & 32 \\
\hline Admission TSH level $(\mu \mathrm{ui} / \mathrm{ml})$ & 264.01 & 180.84 & 36.4 & 600 \\
\hline Admission T4 level $(\mathrm{pmol} / \mathrm{L})$ & 8.80 & 12.20 & 0 & 50 \\
\hline Starting dose of thyroxine $(\mu \mathrm{g} / \mathrm{kg})$ & 8.79 & 6.40 & 4 & 37.5 \\
\hline Control dose thyroxine $(\mu \mathrm{g} / \mathrm{kg})$ & 8.27 & 6.50 & 4 & 37.5 \\
\hline Period to reach control $($ days $)$ & 53.50 & 40.71 & 14 & 120 \\
\hline
\end{tabular}

Regarding linear growth assessment and developmental assessment in the study group (total number of cases 24). Seventeen cases had no change in growth parameter, and five patients had delayed developmental milestones, as seen table 5 .

Table 5. Linear growth and developmental assessment distribution in Al-Imamian Al-Jawadian Teaching Hospital, and Child Central Teaching Hospital patients (n 24).

\begin{tabular}{|l|l|l|l|}
\hline Variable & Frequency & $(\%)$ \\
\hline \multirow{2}{*}{ Linear growth } & No change in growth centile & 17 & 70.8 \\
\cline { 2 - 4 } & Positive change & 7 & 29.2 \\
\hline \multirow{2}{*}{ Development assessment } & Compatible & 19 & 79.2 \\
\cline { 2 - 4 } & Delayed & 5 & 20.8 \\
\hline
\end{tabular}

Data of categorical variables regarding linear growth assessment and developmental assessment of patients in Al-Imamian Al-Jawadian Teaching Hospital, and Child Central Teaching Hospital were as follows; a no change in linear growth in relation to gender, family history. While there was a significant association of positive linear growth increment in symptomatic group of patients (P 0.044), table 6

Table 6. Relationship of the linear growth with the categorical patient's variables (n 24).

\begin{tabular}{|c|c|c|c|c|c|c|}
\hline \multirow{3}{*}{\multicolumn{2}{|c|}{ Patient's variables }} & \multicolumn{4}{|c|}{ Linear growth } & \multirow{3}{*}{$P$ value } \\
\hline & & \multicolumn{2}{|c|}{ No change } & \multicolumn{2}{|c|}{ Positive change } & \\
\hline & & Freq. & $\%$ & Freq. & $\%$ & \\
\hline \multirow{2}{*}{ Gender } & Male & 8 & 88.9 & 1 & 11.1 & \multirow{2}{*}{$P=0.132^{(N S}$} \\
\hline & Female & 9 & 60 & 6 & 40 & \\
\hline \multirow{2}{*}{$\begin{array}{l}\text { Clinical } \\
\text { features }\end{array}$} & Symptomatic & 10 & 58.8 & 7 & 41.2 & \multirow{2}{*}{$P=0.044^{(*)}$} \\
\hline & Asymptomatic & 7 & 100 & 0 & 0 & \\
\hline \multirow{2}{*}{ Family history } & Positive & 3 & 60 & 2 & 40 & \multirow{2}{*}{$P=0.549^{(N S}$} \\
\hline & Negative & 14 & 73.7 & 5 & 26.3 & \\
\hline
\end{tabular}

(NS not statistically significant) (* Significant at alpha level of < 0.05)

A positive change in linear growth centile showed significantly younger aged patients (P 0.025) and higher admission TSH level than no change (P 0.001). While no change in linear growth had significant association with older patients at time of research. 
Table 7. Linear growth distribution within the continuous variables of patients (n 24).

\begin{tabular}{|c|c|c|c|c|c|}
\hline \multirow{3}{*}{ Variable } & \multicolumn{4}{|c|}{ Linear growth } & \multirow{3}{*}{$P$ value } \\
\hline & \multicolumn{2}{|c|}{$\begin{array}{l}\text { No change } \\
\text { (n 17) }\end{array}$} & \multicolumn{2}{|c|}{$\begin{array}{l}\text { Positive change } \\
\text { (n 7) }\end{array}$} & \\
\hline & Mean & $\pm \mathrm{SD}$ & Mean & $\pm \mathrm{SD}$ & \\
\hline Age at first reception in tertiary center (days) & 51.58 & 26.52 & 58.24 & 25.37 & $0.567^{(\mathrm{NS})}$ \\
\hline Age at time of research (months) & 21.05 & 8.95 & 11.78 & 7.40 & $0.025^{(*)}$ \\
\hline Admission TSH level ( $\mu$ ui/ml) & 192.14 & 145.52 & 438.57 & 136.80 & $0.0011^{(*)}$ \\
\hline Admission T4 level (pmol/L) & 9.04 & 12.14 & 8.22 & 13.33 & $0.885^{(\mathrm{NS})}$ \\
\hline Starting dose of thyroxine $(\mu \mathrm{g} / \mathrm{kg})$ & 9.55 & 7.47 & 6.92 & 1.53 & $0.372^{(\mathrm{NS})}$ \\
\hline Control dose thyroxine $(\mu \mathrm{g} / \mathrm{kg})$ & 8.85 & 7.61 & 6.85 & 2.11 & $0.507^{(\mathrm{NS})}$ \\
\hline Period to reach control (days) & 50.12 & 39.16 & 62.00 & 46.36 & $0.528^{(\mathrm{NS})}$ \\
\hline
\end{tabular}

(NS not statistically significant) (* Significant at alpha level of $<0.05$ )

The relationship of the developmental assessment with the categorical patients' variables had no significant association.

Table 8. Relationship of the developmental assessment with the categorical patient's variables (n 24).

\begin{tabular}{|c|c|c|c|c|c|c|}
\hline \multirow{2}{*}{\multicolumn{2}{|c|}{ Patient's variables }} & \multicolumn{4}{|c|}{ Development assessment } & \multirow{3}{*}{ Statistics } \\
\hline & & \multicolumn{2}{|c|}{ Compatible } & \multicolumn{2}{|c|}{ Delayed } & \\
\hline & & Freq. & $\%$ & Freq. & $\%$ & \\
\hline \multirow{2}{*}{ Gender } & Male & 9 & 100 & 0 & 0 & \multirow[b]{2}{*}{$P=0.052^{(N S)}$} \\
\hline & Female & 10 & 66.7 & 5 & 33.3 & \\
\hline \multirow{2}{*}{$\begin{array}{l}\text { Clinical } \\
\text { features }\end{array}$} & Symptomatic & 12 & 70.6 & 5 & 29.4 & \multirow[b]{2}{*}{$P=0.107^{(N S)}$} \\
\hline & Asymptomatic & 7 & 100 & 0 & 0 & \\
\hline \multirow{2}{*}{ Family history } & Positive & 5 & 100 & 0 & 0 & \multirow[b]{2}{*}{$P=0.197^{(N S)}$} \\
\hline & Negative & 14 & 73.7 & 5 & 26.3 & \\
\hline
\end{tabular}

(NS not statistically significant)

There was a significantly higher level of admission TSH in delayed developmental milestones in the study group of patients (P 0.016).

Table 9. Developmental assessment distribution within the continuous variables (n 24).

\begin{tabular}{|c|c|c|c|c|c|}
\hline \multirow{3}{*}{ Variable } & \multicolumn{4}{|c|}{ Developmental assessment } & \multirow{3}{*}{$\mathrm{P}$ value } \\
\hline & \multicolumn{2}{|c|}{$\begin{array}{l}\text { Compatible } \\
\text { (n 19) }\end{array}$} & \multicolumn{2}{|c|}{$\begin{array}{l}\text { Delayed } \\
\text { (n 5) }\end{array}$} & \\
\hline & Mean & $\pm \mathrm{SD}$ & Mean & $\pm \mathrm{SD}$ & \\
\hline Age at reception time (days) & 56.36 & 28 & 43.00 & 11 & $0.314^{(\mathrm{NS})}$ \\
\hline Age at research time (months) & 19 & 9.70 & 16 & 8.72 & $0.524^{(\mathrm{NS})}$ \\
\hline Admission TSH ( $\mu \mathrm{ui} / \mathrm{ml})$ & 219.81 & 154.47 & 432 & 190.05 & $0.016^{(*)}$ \\
\hline Admission T4 (pmol/L) & 8.46 & 11.62 & 10.13 & 15.69 & $0.792^{(\mathrm{NS})}$ \\
\hline Thyroxine Starting dose $(\mu \mathrm{g} / \mathrm{kg})$ & 9.05 & 7.19 & 7.80 & 1.09 & $0.706^{(\mathrm{NS})}$ \\
\hline Thyroxine control dose $(\mu \mathrm{g} / \mathrm{kg})$ & 8.60 & 7.25 & 7.00 & 2.00 & $0.634^{(\mathrm{NS})}$ \\
\hline Period to reach control (days) & 57.47 & 42.99 & 38.80 & 29.44 & $0.373^{(\mathrm{NS})}$ \\
\hline
\end{tabular}

(NS not statistically significant) (* Significant at alpha level of $<0.05$ ) 


\section{Discussion}

A retrospective descriptive study of newborn screening program in Baghdad governorate/ Iraq. The average screening coverage (phenylketonuria, congenital hypothyroidism and galactosemia) in Al-Rusafa and AlKarkh side of Baghdad city was 59.9\% (59.4\%, 60.7\% respectively).

Regarding coverage rates; a neonatal screening study in Alexandria showed a coverage of 49.4\%, 63.3\%, $77.6 \%$, and $82.7 \%$ in the years 2001, 2002, 2003 and in 2005 respectively, ${ }^{(5)}$ a study in Taiwan were program started in 1981, had coverage rate of $90 \%$ in 1990 , and is currently more than $99 \%{ }^{(6)}$ A study in the State of Mato Grosso, Brazil showed a coverage of less than $70 \%,{ }^{(7)}$ other study in Macedonia showed a coverage of $93.4 \% .{ }^{(8)}$ In Madina Al-Monawara the screening program coverage rate was $97 \%$ over 10 years period. $^{(9)}$ Our coverage rates reflect a humble rates in comparison with higher coverage rates exceeding $99.5 \%$ in more developed countries with earlier starting and the international standard of $(99 \%) .{ }^{(10,11)}$

Of presumed causes of low coverage rate and persistent low coverage rates in this study are; missed cases due to delay in BCG vaccination after 2 month of life, deficient resources (filter papers, others) or refusal of parents and considering the test painful and unnecessary, which is related to poor public education of the relatively new program that had been evaluated too early after the its implementation.

The overall proportion of occurrence of CHT is 1:2141, which is comparable to the international figures, Stephen $\mathrm{H}^{(3)}$ mentioned a prevalence of $1 / 3000$ in nationwide screening programs, and Rastogi MV ${ }^{(12)}$ found congenital hypothyroidism occurs in approximately $1: 2,000$ to $1: 4,000$ of newborns. Brown AL et al ${ }^{(13)}$ showed the prevalence is approximately 1 in 3000 newborns. A considerable ethnic variation is present, being low in African-American population in the United States (1:30,000), and 1 in 900 in Asian populations in the United Kingdom Rosenthal M. ${ }^{(14)}$

Hassan FA et $\mathrm{al}^{(15)}$ in a study of tandem mass spectrometry in Cairo, found the birth prevalence of phenylketonuria is 1:12,000, while Waldemar A. Carlo ${ }^{(16)}$ mentioned a prevalence of phenylketonuria 1:20000 in his study. The proportion of occurrence in our study (1:6787), which showed more frequent occurrence, probably related to high consanguineous marriages in Iraq and a different population race.

Present study found the proportion of occurrence of galactosemia is 1:21009, while Waldemar A. Carlo ${ }^{(16)}$ mentioned a prevalence of 1:20000, a finding close to present study. In the united states, the prevalence is approximately 1 in 47000 live births ${ }^{(17)}$, a finding suggests the autosomal recessive disorder with high consanguineous marriages in Iraq.

Regarding hypothyroidism; it was noticed that $56.3 \%$ of confirmed cases of CHT didn't attend the tertiary centers for management, which is explained probably by counseling private sector pediatricians, which is a common practice in Iraq.

Regarding the distribution of the sample; data showed female predominance in the study group of $(62.5 \%)$. A study by Rezaeian $\mathrm{S}^{(18)}$ in Hamadan Province, western of Iran, showed girls accounted for $57.4 \%$ of the cases, and Abdelmoktader $\mathrm{AM}^{(19)}$ in a study in Egypt had a statistically significant association of CHT with female gender. While Immacolata showed CHT is usually sporadic with twice females as males. ${ }^{(20)}$

Most of the cases of hypothyroidism had no family history as most of them result from thyroid dysgenesis in $85 \%$ of permanent, primary $\mathrm{CH}$, while inborn errors of thyroid hormone biosynthesis account for $10-15 \%$ of cases. $^{(3,21)}$

Consanguinity of parents was high which correlates the marriage of cousins in Iraq, and some heritable cases. Stephen $\mathrm{H}^{(3)}$ and Immacolata et al ${ }^{(20)}$ found $\mathrm{CHT}$ is usually a sporadic disease with a 2:1 female to male ratio, while in present study the female : Male patients in Al-Karkh was 15:9, with 1.6:1 ratio. Family 
history was positive in 5 cases of study group (20.8\%), while Castanet $\mathrm{M}$ in his study found familial cases occur in a frequency that is 15 -fold higher than that by chance alone. ${ }^{(22)}$

The presence of clinical signs in the study group was in $(70.8 \%)$, while a study of Immacolata ${ }^{(20)}$, Büyükgebiz $\mathrm{A}^{(23)}$, and Maynika $\mathrm{V}^{(21)}$ revealed clinical features of $\mathrm{CHT}$ at birth are subtle, few or no clinical manifestations at all present due in part to trans-placental passage of maternal thyroid hormone, however in absence of early and adequate treatment, severe CHT may result in serious mental retardation and motor handicaps. The clinically detectable sequels of CHT strongly depend on severity and duration of thyroid hormone deprivation, yet there is a large individual variability in response to treatment. ${ }^{(20)}$ Our study results are explained by the fact that the pediatrician would start asking about possible features as he receives the confirmatory result of CHT in the tertiary centre and would be more oriented with the diagnosis of hypothyroidism at mean age of baby $62 \pm 37.5$ days, which is enough to develop some features if no treatment had not been initiated. Prolongation of physiologic jaundice, constipation, and umbilical hernia were the commonest clinical signs within the symptomatic patients, a finding is also related to delayed starting of treatment, findings similar to Rastogi MV. ${ }^{(24)}$

Regarding linear growth assessment and developmental assessment of Al-Imamian Al-Jawadian Teaching Hospital and Child Central Teaching Hospital patients; only 29.2\% had positive linear growth increment with significant association of symptomatic group of patients after initiation of adequate treatment (P 0.044), which reflects symptomatic cases (severe cases) gets benefit inspite of the initiation of therapy.

A positive change in linear growth centile increment showed a significantly higher admission TSH level than no change (P 0.001). A finding of Rosalind $\mathrm{S},{ }^{(25)}$ found the consequences of severe thyroid dysfunction as manifested by high TSH levels have unique bad effects on growth pattern. While no change in linear growth had significant association with older patients at time of research, which correlates with rapid growth velocity that occurs early in life and decelerates later on.

Delayed developmental milestones had no significant association with the continuous variables of gender, clinical features, family history. While delayed developmental milestones had significant association with high levels of admission TSH. Such finding reflects significant association with more severe cases of CHT as most cases were due to thyroid dysgenesis with associated peaking of TSH levels. ${ }^{(3)}$

Van Vliet $G^{(26)}$ found severely hypothyroid newborns remain at risk of cognitive problems that may be avoided if they had been treated within first two weeks of birth, while the mean age of starting treatment was $62 \pm 37.5$ days in present study, hence the importance of a quick turnaround time of the screening program is essential, a finding that is similar to our above result. Agrawal et al in their study found an inverse relationship between intelligence quotient (IQ) and the age at diagnosis. ${ }^{(27)}$

Minamitani $\mathrm{K}^{(28)}$ found screening results show significant improvement of the intellectual developmental outcome of patients with CHT, with almost no patients having irreversible intellectual disturbance or stunted growth pattern with early initiation of treatment.

\section{Conclusions and recommendations}

*The neonatal screening program in Iraq includes screening for 3 disorders: congenital hypothyroidism, phenylketonuria and galactosemia with low coverage rate in Baghdad as compared to the international figures.

*Severe cases of CHT are associated peaking of TSH levels, delayed developmental milestones. 
*Efforts to bypass the drawbacks of work routines in neonatal screening program to increase the screening coverage above $59.9 \%$.

*Enhance public education to shorten time of diagnosis and starting treatment, least sequel start later on.

*Encourage PHC personnel and central laboratory for direct communication systems in notification of confirmed cases to attend the tertiary centers.

*Expansion of the program through involvement of multiple disorders screening, and involvement of whole Iraq governorates.

\section{References}

1. U.S. Agency for International Development. National Guideline of Newborn Screening for Care Providers in PHC Centers. Iraq 2014. 45p. http://phciraq.org/www.usaid.gov

2. Aneela Anjum, Muhammad Faheem Afzal, Syed Muhammad Javed Iqbal, Muhammad Ashraf Sultan, and Asif Hanif.

3. Stephen H. LaFranchi and Stephen A. Huang, Stephen A. Huang. Hypothyroidism. In Robert M. Kliegman, and Richard E. Behrman, Nelson TEXTBOOK of PEDIATRICS, Ed 20, 2016, Elsevier Inc. Chapter 565, 2665-68

4. National Center for Health Statistics in collaboration with the National Center for Chronic Disease Prevention and Health Promotion. http://www.cdc.gov/growthcharts. modified 4/20/01

5. Dabbous NI, Abd El-Aziz HM, Abou El-Enein NY, Kandil HH, El-Kafoury AA. Indicators of the screening program for congenital hypothyroidism in alexandria. $\mathrm{J}$ Egypt Public Health Assoc. 2008;83(3-4):307-27.

6. Hwu WL, Huang AC, Chen JS, Hsiao KJ, Tsai WY. Neonatal screening and monitoring system in Taiwan. Southeast Asian J Trop Med Public Health. 2003;34 Suppl 3:91-3.

7. Stranieri I, Takano OA. Evaluation of the Neonatal Screening Program for congenital hypothyroidism and phenylketonuria in the State of Mato Grosso, Brazil. Arq Bras Endocrinol Metabol. 2009 Jun;53(4):446-52.

8. Anastasovska V, Koviloska R, Kocova M. High incidence of congenital hypothyroidism in one region of the republic of macedonia. Balkan J Med Genet. 2014 Dec 11;17(1):31-6.

9. Al-Maghamsi MS, Al-Hawsawi ZM, Ghulam GN, Okasha AM. Screening for congenital hypothyroidism in North-West region of Saudi Arabia. Saudi Med J. 2002; 23:1518-21

10. Pollitt RJ, Green A, Mc Cabe CJ. Neonatal screening for inborn errors of metabolism: cost, yield and outcome review. Health Technology Assessment. 1997; 1 (7). Available: www.ncchta.org.

11. American Academy of Pediatrics. Update of newborn screening and therapy for congenital hypothyroidism. Pediatrics. 2006; 117: 2290-303

12. Rastogi MV, LaFranchi SH. Congenital hypothyroidism. Orphanet J Rare Dis. 2010 Jun 10;5:17

13. Brown AL, Fernhoff PM, Milner J, McEwen C, Elsas LS. Racial differences in the incidence of congenital hypothyroidism. The Journal of pediatrics 1981; 99:934-936

14. Rosenthal M, Addison GM, Price DA. Congenital hypothyroidism: increased incidence in Asian families. Arch Dis Child 1988; 63:790-793

15. Hassan FA, El-Mougy F, Sharaf SA, Mandour I, Morgan MF, Selim LA, et al. Inborn errors of metabolism detectable by tandem mass spectrometry in Egypt: The first newborn screening pilot study. J Med Screen. 2016 Jan 20. 
16. Waldemar A. Carlo. The newborn infant, in Robert M. Kliegman, and Richard E. Behrman, Nelson TEXTBOOK of PEDIATRICS, Ed 20, 2016, Elsevier Inc. Chapter 94, 794-802

17. Priya S. Kishnani and Yuan-Tsong Chen. Defects in Galactose Metabolism. In Robert M. Kliegman, and Richard E. Behrman, Nelson TEXTBOOK of PEDIATRICS, Ed 20, 2016, Elsevier Inc. Chapter 87.2, 726-27

18. Rezaeian S, Moghimbeigi A, Esmailnasab N. Gender differences in risk factors of congenital hypothyroidism: an interaction hypothesis examination. Int J Endocrinol Metab. 2014 Apr 1;12(2):e13946.

19. Abdelmoktader AM. Risk factors for congenital hypothyroidism in Egypt: results of a population case-control study (2003-2010). Ann Saudi Med. 2013 May-Jun;33(3):273-6. doi: 10.5144/02564947.2013.273.

20. Immacolata Cristina Nettore, Gianfranco Fenzi, and Paolo E. Macchia. Genetic Defects in Thyroid Hormone Supply. In Endotext [Internet]. De Groot LJ, Beck-Peccoz P, Chrousos G, et al., editors. South Dartmouth (MA): MDText.com, Inc.; 2000

21. Maynika V, Rastogi and Stephen H LaFranchi. Congenital hypothyroidism. Orphanet J Rare Dis. 2010; 5: 17. Published online 2010 Jun 10.

22. Castanet M, Polak M, Bonaiti-Pellie C, Lyonnet S, Czernichow P, Leger J. Nineteen years of national screening for congenital hypothyroidism: familial cases with thyroid dysgenesis suggest the involvement of genetic factors. The Journal of clinical endocrinology and metabolism 2001; 86:2009-2014

23. Büyükgebiz A. Newborn screening for congenital hypothyroidism. J Pediatr Endocrinol Metab. 2006 Nov;19(11):1291-8.

24. Rastogi MV, LaFranchi SH. Congenital hypothyroidism. Orphanet J Rare Dis. 2010 Jun 10;5:17.

25. Rosalind S. Brown, Disorders of the Thyroid Gland in Infancy, Childhood and Adolescence. http://www.ncbi.nlm.nih.gov/books/NBK279032/ Last Update: March 21, 2012.

26. Van Vliet G, Czernichow P. Screening for neonatal endocrinopathies: rationale, methods and results. Semin Neonatol. 2004 Feb;9(1):75-85.

27. Agrawal P, Philip R, Saran S, Gutch M, Razi MS, Agroiya P, et al. Congenital hypothyroidism. Indian J Endocrinol Metab. 2015 Mar-Apr;19(2):221-7

28. Minamitani K, Inomata H. Neonatal screening for congenital hypothyroidism in Japan. Pediatr Endocrinol Rev. 2012 Oct;10 Suppl 1:79-88. 